\title{
Reification and Immaterial Production
}

\author{
Dimitris Gakis \\ Institute of Philosophy, KU Leuven, Belgium \\ dimitris.gakis@kuleuven.be
}

[This is the peer reviewed version of the following article: Gakis, D. (2019) Reification and immaterial production. Philosopby \& Social Criticism, which has been published in final form at https://doi.org/10.1177/0191453719829188].

\section{Introduction}

The concept of reification has a rather complex, but nevertheless interesting, intellectual history. From a politico-philosophical point of view, the starting point of this history can be traced back to Marx's mature writings. From the composition of the Grundrisse der Kritik der Politischen Ökonomie in the winter of 1857-8 (e.g. see Marx 1993, p. 160) onwards (e.g. see Marx 1990, pp. 209, 1054-6; 1991, pp. 969, 1020) Marx uses the terms 'Verdinglichung' and 'Versacblichung' in order to discuss the objectification of human activity and the fetishist transformation of social/human relations into relations between things - whether Marx uses the terms interchangeably and, if not, how each term relates to objectification and fetishism has been an object of considerable debate within Marxian and Marxist scholarship, the dominant view still being that the terms were used by Marx as semantically equivalent. But the locus classicus of Marx's own discussion and analysis of reification, although neither 'Verdinglichung' nor 'Versacblichung' are used there, is traditionally considered to be the fourth section of the first chapter of the first volume of Das Kapital, i.e. the section on 'The Fetishism of the Commodity and Its Secret' (Marx 1990, pp. 163-177). Despite the explicit and implicit references to and discussions of reification in the first and third volume of the Capital (the former having been published in 1867 and the latter in 1894) the themes of reification and commodity fetishism started 
getting prominence only after the publication of Lukacs's seminal work History and Class Consciousness in 1923. A large and crucial part of that work (viz., the chapter on 'Reification and the Consciousness of the Proletariat' (see Lukacs 1971, pp. 83-222)) is occupied by Lukacs's analysis of the phenomena of reification and commodity fetishism, with reification, as a historical specific result of "the structure of commodity-relations" in capitalism, being proclaimed not (just) "the central problem in economics", but "the central, structural problem of capitalist society in all its aspects" (ibid. p. 83). In the same year (1923), Rubin's Essays on Marx's Theory of Value is published in the Soviet Union, a work that highlights the key position of Marx's discussion of commodity fetishism in the development of his theory of value, which, nevertheless became widely accessible to the West only much later.

What actually offered a decisive boost in the discussions of reification was the publication of Marx's earlier (to the Capital) manuscripts, such as the Economic and Philosophic Manuscripts of 1844 in 1932 and the Grundrisse in 1939, with alienation (as Entfremdung, Entäußerung, or Veräußerung) becoming one of the central concepts of Marxist theory and the concept of reification being directly associated to it. ${ }^{1}$ Thus, the wider problematics related to issues of alienation, reification, and commodity fetishism, as well as the concepts as such and the relations between them, become a major theme of discussion in post-war Western Marxism and critical and/or radical social/political thought in general - from the Frankfurt School (e.g. Adorno, Marcuse, Fromm) and the broader tradition of humanist Marxism (e.g. Lefebvre, Bloch) to the Situationists (e.g. Debord), the Socialisme on Barbarie group (e.g. Castoriadis) and, in a critical way, early post-structuralism (e.g. Althusser) - and not only in philosophy and theory, but also in other branches of human intellectual activity such as sociology, psychology, and literature. The 1960s can be considered to constitute the high point of those theoretical discussions, with the various and numerous social and political movements and revolts in the end of the decade signifying their practical counterpart. From the beginning of the 1970s onwards - in the aftermath of those movements and revolts and under the expanding influence of poststructuralism and its criticisms of humanist Marxism - alienation, reification, and commodity fetishism loose their central position in radical thought and critical theory. Studies on alienation such 
as Meszaros (1970), Schacht (1971), and Ollman (1976) and humanist Marxist philosophical movements, such as the Yugoslavian 'Praxis School', provide a kind of closure to a thematics which gets to be rather marginal in the new critical theoretical paradigm of 'biopolitics', under which concepts such as 'value', 'exploitation', 'labor', and 'commodity' become secondary, if not even irrelevant in certain cases, to the new forms of analysis based on concepts such as 'desire', 'subjectification', 'discipline', and 'power'. There have been of course notable contributions to the broader thematics of alienation, reification, and commodity fetishism from the end of the 1970s onwards - see, for example, the works in the 1980s of members of the German Krisis group such as Kurz, Scholz, Trenkle, and Jappe or a diversity of works ranging from Postone's unorthodox Marxism (see Postone 1993) to Rosa's work on acceleration as the driving force of modern capitalism (see e.g. Rosa 2010) and from Italian post-Autonomia (e.g. Berardi 2009, Virno 2015) to third generation Frankfurt school theory (e.g. Honneth 2012) - but it seems that for the triptych of alienation, reification, and commodity fetishism, to a large extent and in terms of popularity, the "good old" days are gone.

In the same period (the 1970s) as the concepts of alienation, reification, and commodity fetishism were falling out of political and philosophical fashion - considered, among others, as too "Hegelian", an accusation that has been constantly accompanying the whole thematics from its very birth (i.e., the works of Lukacs and Rubin) as part of the criticisms developed by the tradition of orthodox, scientific, Soviet-influenced Marxism - and in response to the insurrectionary potentialities of the antagonistic (to capitalism) movements of the 1960s, a number of crucial developments in the organization of labour emerge, as has been emphatically stressed in the works of many Italian postAutonomist thinkers (see for example Lazzarato 1996 and Hardt and Negri 1994; 2000; 2004; 2009; 2017). Starting with the end of the Bretton Woods System and the suspension of the dollar's convertibility into gold in 1971-73 - a key turning point that signals the radical autonomization of financial capital - one may trace various crucial changes in the form of capitalism from the mid-/late 70s onwards. Changes such as the transition from the Fordist to the post-Fordist model of production and social regulation and from the hegemony of material (as industrial) to the hegemony 
of immaterial (as cognitive and/or affective) labour, the demise of the (Keynesian) planner-state and the rise of the crisis-state with the dominance of the neoliberal economic model, and the resulting alterations in the composition of capital and the working classes, with the biopolitical mode of production (i.e., the production of subjectivities, social relationships, and forms of life) unfolding in the centre of the new hegemonic site of production of value, namely, the contemporary metropolis.

The primary goal of the present article is to discuss reification in light of the above changes addressing the question of whether and how reification (and the congruent concepts of alienation and commodity fetishism) may be (re)approached in the context of the hegemony of immaterial/biopolitical labour. More specifically, this article aims at investigating the question, first, of reification's relevance to the new political, social, economic status quo and the new composition of labour and, second, of if and how reification changes itself, from both a quantitative and a qualitative point of view, in this new context. In order to address the above questions, and after this introduction, the article proceeds in the following manner. In the next section, I discuss the concept of reification (and its relation to alienation and commodity fetishism) with the intention of clarifying the ways in which it is understood and used in the presently developed approach - a similar, but briefer, elucidation takes place also with regard to the concepts of hegemony and immaterial production. In the third section of the article, I engage with the theme of the place and nature of reification in contemporary capitalism, starting from Hardt and Negri's analysis of the latter and their emphasis on some of its distinctive characteristics such as the real subsumption of labour, society, and life under capital and the demise of the (sharp) division between labour time and leisure/free time. Through this discussion I highlight how reification under the hegemony of immaterial labour becomes, on the one hand, even deeper and more widespread and, on the other hand and at the same time, (potentially) easier to diagnoze, diminish, or overcome, due to the increasing emergence of the common as a social relation antagonistic to the capitalist ones. In the fourth and concluding section of the article, I, first, stress the emergence of the production of subjectivity (and thus of its constitutive spheres of the symbolic and the affective) as the new hegemonic terrain of the intensified struggle between capital and labour. Then, I sketch some of the ways in which Wittgenstein's later 
philosophy, interpreted in a rather unorthodox way as a simultaneous critique of the reification of the symbolic (language) and the 'inner' (affects) and a praise of the common, may contribute to the discussion of the place, role, and nature of reification in the context of the hegemony of immaterial/biopolitical production.

\section{The Concept of 'Reification' (And a Few Remarks on 'Hegemony' and 'Immaterial Production')}

The attempts over the last almost hundred years to answer the question of what reification, alienation, and commodity fetishism are, of the relation between them, and of the role they play in capitalism and human life have resulted in a vast scholarship and a wide range of approaches to the topic some of the most significant ones have already been highlighted in the introduction above. Through these attempts, many more crucial questions (and respective answers) have risen regarding the broader thematics, such as the following: How are the concepts of reification, alienation, and commodity fetishism to be positioned in relation to exploitation, technology, progress, reason, language, consciousness, and human nature? Are the phenomena designated by these concepts sociohistorical (i.e., specific to modernity and capitalism) or ontological (i.e. part of the human nature/condition)? Are these phenomena of an epistemological or a psychological nature, are they agential or structural, individual or collective? Can/should they be overcome and, if yes, how? The goal of this section is not to engage with the aforementioned questions, and the various actual and possible answers, in a direct and exhaustive way - that is a thematics so vast and complex that its proper discussion far exceeds the scope and limits of this article. Rather, what I aim to do in this section is just to briefly clarify the way these concepts, and especially reification, are understood and used for the specific purposes of our approach by highlighting some of their main relevant characteristics, without any pretension that this is the one and only, right, real, or proper way to deal with them. 
Such an approach as the one adopted here is not guided by an abstract methodological pluralism, but rather stems from the (Wittgensteinian) insight that the diversity, complexity, and, sometimes, generality, vagueness, and confusion that the relevant bibliographical discussion exhibits is not the outcome of insufficient analysis, but in many cases actually reflects the character of the specific concepts, their uses, and their in-between relations. To wit, alienation, reification, and commodity fetishism are considered here as family-resemblance concepts; this means to suggest that all the different individual instantiations of each term in the various different contexts, which are all grouped together under the same general concept, are not connected via the existence of a single characteristic (or a single set of characteristics) identical in, or shared by, all of them, i.e., a common essential feature, but rather via a network of overlapping similarities among them. ${ }^{2}$ What makes the specific case under discussion more complex, is the fact that there is often a considerable overlap between the uses of the three distinct concepts (alienation, reification, commodity fetishism) too. Thus, even if one adopts one of the traditional conceptions of the relation between the three concepts, according to which reification is considered as a specific type/form of alienation and commodity fetishism as a specific type/form of reification (see Petrovic 1991, p. 465), the plurality and multifariousness of the uses of the concepts to be found in the relevant discussions suggest that there is no common essential feature to be found in all their different uses. Reification, alienation, commodity fetishism; all three concepts may be found to denote externalization, objectification, heteronomy, mystification, separation, loss, or estrangement in all different kinds of contexts and combinations and from all different kinds of perspectives. ${ }^{3}$ That is why it is of crucial importance to be clear about the specific ways in which the terms are used in the context of the present article and to highlight those of their aspects that are most relevant for our specific purposes.

The starting point for our specific approach to reification is provided by Petrovic's, one of the prominent figures of the Yugoslavian 'Praxis School', definition of the concept, which reads as follows: 
The act (or result of the act) of transforming human properties, relations and actions into properties, relations and actions of man-produced things which have become independent (and which are imagined as originally independent) of man and govern his life. Also transformation of human beings into thing-like beings which do not behave in a human way but according to the laws of the thingworld. (Petrovic 1991, p. 463)

The above definition of reification exhibits two main advantages. First, it encapsulates Marx's discussions of commodity fetishism and reification in the first and third volume of the Capital, as well as the main characteristics of Lukacs's interpretation and use of the notion, in a clear, concise, and rounded manner. Second, and most importantly, it manages to a large extent to achieve the thin balance between generality and specificity that is required from the term as an analytical concept. Terms such as 'reification', 'property', 'value', 'commodity', 'capital' do not designate some kind of metaphysical/transcendental objects or entities - actually, that would be a manifestation of a reified perspective - but they rather refer, describe, and/or express social relations, and thus their use should always be characterized by the required openness and flexibility as conditioned by the characteristics of each specific occasion and context. It is on that basis that the concept of reification can be further specified for the purposes of the present article as follows. First, as the point of conjunction of objectification (relations between humans and human beings are transformed into relations between things and thing-like entities respectively), alienation (as separation: human-produced things as independent, separated entities), and fetishism (human-produced entities that govern human life, which is of course also a form of heteronomy). ${ }^{4}$ In capitalism, where human-produced things and entities take the commodity-form, reification is further specified as commodity fetishism. And, it is indeed reification as commodity fetishism, as a socio-historical phenomenon distinctive of the capitalist mode of production, and not the aspects of reification as an ontological condition, that is of interest for our purposes. ${ }^{5}$ Second, reification as an act, is not (just) a mental state characteristic of (just) human consciousness, but a characteristic of praxes, stances, ethe, perspectives, modes of behavior, institutions, and forms of life. That is why it has both agential and structural, individual and collective, psychological and epistemological, ethical and metaphysical, historical and ontological aspects, among many others. ${ }^{6}$ It is a phenomenon related to consciousness as far as consciousness is to be 
understood in an irreducibly social and practical manner, as approached for example, not only by Dewey and Heidegger as Honneth observes (see Honneth 2012, pp. 28-40), but also by Marx (see Marx and Engels 1998, p. 49 and Marx 1994) and the later Wittgenstein too (see for example his discussions of the idea of a private language and of psychological concepts, "inner" processes, and mental states in Wittgenstein (2001, \$\$243-693) - for Wittgenstein an "inner process" stands always “in need of outward criteria" (ibid. §580)).7

A further third specification regarding reification is that it is approached here as indeed the basis for the "complete mystification of the capitalist mode of production" (Marx 1991, p. 969). As discussed by Marx in the first chapter of the first volume of the Capital (Marx 1990, pp. 125-177) the products of human labour exhibit in capitalism a dual character; not only that of use-value - the value of the products of concrete labor as realized in their use/consumption for the satisfaction of material and immaterial needs - but also that of exchange-value - as congealed abstract labour (time), as the quantitative homogenization and commensuration of qualitatively heterogeneous and incommensurable labour (time) and use-values. Human products take the commodity form in the specific exchange-based system of capitalism through the transformation of use-value into a mere prerequisite and depository of exchange-value as long as commodities are primarily produced to be exchanged and not to satisfy human needs (i.e. social use-values are obfuscated, and displaced as a determinant of value, by exchange-values through the capitalist division of labor). The bond between producers, their labor, its products, and their use-values is mystified. The exhaustion of value by exchange-value (the commodity form), while an expression of the capitalist form of social production, viz. of socio-historically specific social relations of production based on certain specific characteristics such as the division of labour and the function of abstract labor time as the measure of (exchange-)value, appears as a "self-evident and nature-imposed necessity" (ibid. p. 175). Thus, the commodity form reflects "the social characteristics of men's own labour as objective characteristics of the products of labour themselves, as the socio-natural properties of these things" (ibid. pp. 164-165), with the (relations between the) labour products taking a life of their own, ruling, in the end, the producers instead of being ruled by them (see ibid. pp. 165-168), i.e. reification, as 
described above. But what needs to be stressed most of all in regard to the further specification of reification as a form of mystification is that although the form of relation between things into which the relations between humans are transformed is a "fantastic", "illusionary" one (see ibid. pp. 165, 176), that does not make it less real. That is to say, as far as capitalism persists, or, to be more precise, as far as the law of value is operating under the command of capital - this point is discussed in some more detail in the next section - reification is a "real mystification", ${ }^{8}$ social relations really take the form, i.e. not in an imaginary, but in an inverted manner, of "material [dinglich] relations between persons and social relations between things" (ibid. p. 166). The fourth, and last, specificatory point is directly connected to this peculiar character of reification as a real mystification and has to do with the way that such an understanding of reification informs also its critique. Traditionally, the critique of reification (as well as of alienation and commodity fetishism) as a mystifying phenomenon has been based on the distinction between existence (or appearance) and essence and consequently on some kind of an account of human nature or essence. To wit, the critique of the various reified perspectives, social relations, practices, and forms of life has been based on the premise that they constitute a perverted, deficient, false, or unauthentic mode of social being, a deviation from their true, original, authentic, natural forms, from our essential self and from our (real, actual) human nature or essence - a critique of reification of such a kind is mainly characteristic of the broader tradition of humanist Marxism (see for example Marcuse 2002 and Fromm 2004), is mostly informed by Marx's early views on alienation (and especially his notion of the species-being), and was in the centre of the debate between humanist Marxism and anti-humanist, post-structuralist Marxism (as expressed for example in Althusser 2005). What is important to note in any case is that this is not the only way in which a critique of reification may be articulated, especially taking into account its character as a real mystification. The criteria for such a critique may not be provided anymore by a hidden or lost, true, authentic, essential human nature that needs to be salvaged or saved (resulting in rather essentialist or identitarian stances), but from the (political) project of the invention, production, and development of new potential anthropological types or forms of life, alternative and antagonistic to the capitalist/reified ones. ${ }^{9}$ If "all reification is forgetting" (Horkheimer and Adorno 2002, p. 191), then this forgetting: i) may be understood not only as concerning who/what we actually 
are (or have been) as human beings, but also what we can, might, or should come to be in the future, ${ }^{10}$ and ii) does not necessarily need to point towards a deeply hidden or rarefied truth, but can be rather understood as (also) a case of failing to notice something because it is always before our eyes (see Wittgenstein 2001, \$129).

Before moving to the next section, a few remarks on the way in which the notions of 'hegemony' and 'immaterial production' are employed in this article are also in order. Regarding 'hegemony', the term is used here, following Hardt and Negri, in a rather minimal manner in order to denote not quantitative predominance, but qualitative leadership, and, especially in connection to labour and production under contemporary capitalism, to highlight the shift of the economic centre of gravity and the way in which the qualitative dominant (immaterial) form(s) of production and labour gradually affect and transform the rest and society in general. ${ }^{11}$ Thus, hegemony is to be further qualified, not just as qualitative, but also as tendential, i.e. as dealing with evolving networks of trends in production, labour, and life (and not with any kind of (quasi-)scientific, quantifiable, deterministic "laws"). And it is actually the uneasiness and confusion over this qualitative and tendential character of hegemony, i.e. over the idea that something can be hegemonic (as dominant) without exhibiting quantitative, and thus also quantifiable, predominance, that has served as a basis for many of the criticisms of Hardt and Negri's works. ${ }^{12}$ As far as 'immaterial production/labour' is concerned, the concept's employment in this article is largely informed by the way the concept emerged in (and became central for) the Italian (post-) Autonomia tradition, and especially the works of Hardt and Negri, and it is understood as designating the form(s) of labor that produce "information, knowledges, ideas, images, relationships, and affects" (Hardt and Negri 2004, p. 65). ${ }^{13}$ Immaterial labour may be thus further specified as: i) cognitive labour (primarily linguistic or intellectual labor that produces ideas, symbols, codes, texts, cultural products, linguistic figures, images, etc.) and affective labour (labor that produces or deals with affects, such as feelings of ease, well-being, satisfaction, excitement, passion, etc.) (ibid. p. 108), ii) biopolitical production, in the sense that it produces subjectivities, social relations, and forms of life, being thus engaged with social life in its entirety (ibid. pp. 94, 109-110), and anthropogenetic production, as the production of humans by 
(means of) humans (Hardt and Negri 2017, pp. 122, 147), ${ }^{14}$ and iii) immaterial only with regard to its products and not to the nature of labour itself, which remains indeed material, involving, as all labor does, human bodies and brains (Hardt and Negri 2004, p. 109). Yet, there are still two points that, despite the brief but explicit references to them by Hardt and Negri, often go unnoticed, giving rise to certain confusions and misunderstandings regarding the character of immaterial production and stand thus in need of extra emphasis. The first has to do with the distinction between cognitive and affective labour as the two principal forms of immaterial production. It should be stressed that this distinction should not be conceived as a sharp and exhaustive one. Actually, in most forms of immaterial labour aspects of both cognitive and affective production coexist and are combined, creating a hybrid cognitive-affective form of labour (see ibid. 108-9). Hence, cognitive and affective labour should not be viewed as two separate (as mutually exclusive) forms that immaterial labour may take, but as comprising a continuum on the edges of which lie forms of labour in which one of the two aspects is predominant (e.g. sex work with regard to affective labour and higher education teaching/research with regard to cognitive labour). ${ }^{15}$ The second point concerns the material aspects of immaterial production. Again, material and immaterial labour should not be conceived as two separate (as mutually exclusive) forms of labour, but as two aspects of labour that most often mix and combine, forming thus a continuum (see ibid.). But what is important to note is that this interpenetration of the material and the immaterial does not concern only the character of labour itself, as Hardt and Negri suggest, but also, and to a certain extent, the products of labour too. To wit, immaterial products also exhibit an irreducible material aspect - subjectivities, social relations, and forms of life are always spatio-temporally situated and thus embodied or materialized in a sensuous or corporeal manner. ${ }^{16}$ Furthermore, the model of the production of humans by humans may not be viewed as standing in opposition or contrast to the model of the production of commodities by means of commodities as Hardt and Negri hold (see Hardt and Negri 2017, pp. 122), but rather, and especially under the current forms of the command of capital as it will be discussed right away in the next section, as the latter model's transformation, with humans and their relations being commodified. From such a perspective, it would be more accurate to refer to the material and immaterial aspects of commodities, rather than to material or immaterial commodities as such. ${ }^{17}$ 


\section{Reification and the Real Subsumption of Life under Capital}

The hegemony of immaterial production, i.e. the qualitative and tendential predominance of immaterial forms of labour, is one of the main distinctive characteristics of late capitalism, but not the only one - the demise of the welfare-state and the rise and dominance of the neoliberal politicaleconomic model, with finance capitalism at the forefront, is certainly another important distinctive feature of postindustrial society. Be that as it may, what is most important to stress for our purposes is that the recomposition of capital and labour initiated in the early 1970s, signifying the real subsumption of not just labour, but of society and life itself within capital (see Hardt and Negri 2009, pp. 137-142, 228-233; 2017, pp. 39-42, 178-182), problematizes some of the most fundamental (sharp) distinctions in classical political economy, but also in Marx's work too, such as the one between labour time and leisure time, between consumption and production, between productive, reproductive, and unproductive labour, in the end resulting in the diffusion of labour into (the whole of) life (see e.g. Hardt and Negri 2004, pp. 140-153; 2009, pp. 131-137, 290-295, 312-321). Value produced in the context of the hegemony of immaterial labour is not just immeasurable, but actually beyond measure (Hardt and Negri 2009, pp. 268-274; 2017, pp. 128-131, 162-166, 222-225). Thus, Marx's labour theory of value, as developed in the first chapters of Capital with the analysis of commodity fetishism being an integral part of it, appears to become less relevant, if not irrelevant, and the law of value is being put into crisis (see Negri 1988 for one of the first formulations of the idea of the crisis in the law of value in his writings and Hardt and Negri 2004, pp. 140-153; 2009, pp. 312-321; 2017, pp. 39-42, 203-206 for its later versions). In the light of such an analysis of the development of capitalism, reification - as a concept developed and analyzed in an era where material/industrial production was predominant and the paradigmatic form of a commodity was that of a material object/thing - seems also to have less relevance, if any, for an era such as ours paradigmatically characterized by immaterial (as also biopolitical) production. It comes as no surprise then that some (post-)Autonomia thinkers, such as Berardi, hold that in the postindustrial context, 
alienation no more takes the form of reification (as in the industrial context), but that of de-realization (see Berardi 2009, pp. 106-116).

Nonetheless, that is not the end of the story when it comes to the issue of reification's relevance for immaterial production. The main reason for that is that while it may well be the case that the labour theory of value is nowadays an insufficient conceptual tool when it comes to the critical analysis of our actual contemporary practices and relations of production and that the law of value has indeed been thrown into crisis since the early 1970s, the law of value remains still operative. Negri in fact acknowledges that although the law of value has indeed been thrown into crisis - as the "moving contradiction" between the continuously reducing socially necessary labour time and the imposition of labour time as the sole measure of value and wealth develops (see Marx 1993, p. 706) - it nevertheless still somehow remains in force, even if not exhaustively and in a rather arbitrary, "as-if" manner, being actually socio-politically (re)enforced under capital's command and control (see for example Negri 1988; 1991 for earlier formulations and Hardt and Negri 2009, pp. 50-55, 137-149; 2017, pp. 111-115, 155-225 for more recent ones). In the end, value produced as/in common in biopolitical labour is still expropriated by (finance) capital, albeit not exhaustively as we will discuss below, and takes the commodity form, whether material and/or immaterial. The increasingly dominant extractivist/rentier forms of late capitalism do not make generalized exchange irrelevant. Or, to put it a bit differently: the (labour) theory of value may be dead, but the law of value is still alive - although its health is rather debatable. ${ }^{18}$ In any case, abstract labour (time) is still imposed by capital as the sole measure of value and as long as the law of value is enforced, the commodity form of the product of labour and the value-form of the commodity are still imposed as social relations, forced labour (as capitalism's blackmail for survival) remains the fundamental means of organizing society (see Cleaver 2000, p. 81-94), and, thus, the concept of reification, as analysed in the previous section, still remains, at least potentially, relevant for the analysis of late capitalism. ${ }^{19}$ Therefore, we shall examine in some more detail how reification is affected, both from a quantitative and a qualitative point of view, and may be (re)approached in the context of the changes in the form of capital(ism) and labour discussed so far. 
On the one hand, reification in the context of the hegemony of immaterial production seems to be intensified, both quantitatively and qualitatively. From a quantitative point of view, through the real subsumption of labour, society, and life under capital reification appears to become more widespread, as continuously more and more social relations and practices, as well as individual and collective subject(ivitie)s, are reified and commodified. The hidden production of value - in the form of exploitative private data mining with regard to trends, preferences, views, etc. - through our everyday use of services, networks, platforms and media, such as Google, Facebook, Instagram, and YouTube; the role of "immaterial objects", such as clicks, views, follows, likes, statuses, and emojis, and of "web influencers" and celebrities in the production of value, together with capital's war on web neutrality and privacy; hidden and/or targeted advertising, from personal on-line posts and forced product and service reviews to opinion articles and cultural artifacts (movies, TV series, video clips), especially with regard to the lifestyle niche (beauty, fashion, etc.); peer-to-peer economic exchanges in transportation (Uber), knowledge/intelligence (Amazon Mechanical Turk), food delivery (Foodora, Deliveroo), holiday/travelling (Airbnb), etc. or in the form of the various online crowdfunding plattforms; the production of subject(tivitie)s as shaped by financialization (credit cards, loans, etc.); the commodification of public utilities, social security, health care, education, etc.; the amateurization of the sex/porn industry; the valorization and reification of our social capacities for e.g. caring, helping, supporting, loving in affective labour and of our social intellectual production in the form of copyrights, logos, patents, etc. in cognitive labour. All the above are just a few examples of new or expanded ways and fields in which reification emerges as ideas, affects, information, images, experiences, as well as social relations, subjectivities, and forms of life are increasingly commodified. This quantitative intensification of reification is an inherent aspect of the real subsumption of social life under capital, demonstrating a tendential identification of life with labour (as the production of value). It is no more just the spatially and temporally limited labour site and time, but the whole of society and life that become the site of reification. This may initial seem as just a mere rediscovery of Lukacs's original approach to reification as a central phenomenon not just in capitalist production, but in capitalist society in general (Lukacs 1971, p. 83), however it is actually quite a different, and a 
rather distinctive, aspect of reification in the context of the hegemony of immaterial production. Reification is no more to be approached as being merely transferred, projected, or expanded from social relations of production to social relations in general, but social life in general becomes directly productive of value. ${ }^{20}$ And this signifies, not just the quantitative, but also the qualitative intensification of reification in two important respects.

First, in biopolitical production, where (wo)man is the means of production of (wo)man, (wo)man becomes both fixed and circulating capital, both the subject and the object of production - human capital is unceasingly (self-)valorized. As Hardt and Negri observe, one distinctive feature of immaterial/biopolitical labour is that "the object of production is really a subject, defined, for example by a social relationship or a form of life" (Hardt and Negri 2009, p. 133). ${ }^{21}$ The fact that these social relations or forms of life are immaterial - in the sense discussed in the previous section - does not mean that they cease to be of an objective nature; under the command of capital and the enforcement of the law of value, subject(ivitie)s, social relations and forms of life are still objectified as the objects of production, as the new immaterial commodity form, as immaterial objects/commodities. In the case of capitalist biopolitical production, subject(ivitie)s, social relations, and forms of life are objectified and reified "as such", i.e. without the mediation of material objects as in the case of material/industrial production, while of course still remaining exchangeable with material objects, contributing thus to the further abstractization of labour. Under the hegemony of immaterial production, reification itself becomes immaterial, reaching, one could argue, its highest or deepest form. ${ }^{22}$ Second, reification in late capitalism becomes deeper, since this kind of immaterial reification involves the cognitive and affective aspects of the human form(s) of life - aspects constitutive of human subjectivity par excellence. ${ }^{23}$ As Hardt and Negri observe: "when affective production becomes part of waged labor it can be experienced as extremely alienating: I am selling my ability to make human relationships, something extremely intimate, at the command of the client and the boss" (Hardt and Negri 2004, p. 111). But what needs to be stressed is that what is reified and commodified in immaterial labour (ideas, affects, etc.) is indeed something intimate, but not something private. Immaterial reification does not concern the objectification, alienation, and fetishization of our 
supposed individual capacities (as privately owned) for social production and their products, but the objectification, alienation, and fetishization of the very social relations and practices that constitute each subject as an individual subject. ${ }^{24}$

On the other hand, the potentialities for the diminishing or overcoming of reification in the context of the hegemony of immaterial production seem to be also intensified. For that, the emergence of the common as a fundamental defining characteristic of immaterial/biopolitical production and a significant, if not the most significant, focal point of political struggle, as Hardt and Negri continuously emphasize, ${ }^{25}$ plays a crucial role. The notion of the common may be understood in Hardt and Negri works in two important ways. First, from a philosophical point of view, as a Spinozian-Wittgensteinian approach to a form of intersubjectivity that comes to replace traditional philosophical dichotomies such as universal/particular, public/private, subject/object, identity/difference, etc. (see e.g. Hardt and Negri 2009, pp. 119-128). And second, from a political point of view, as a social relation antagonistic to the ones characteristic of capitalism, such as capital, value, property, etc. (see for example ibid. pp. vii-xiv, 107-118, 119-128, 268-274). Hardt and Negri refer with the notion of the common not only to "the common wealth of the material world" (ibid. p. viii), such as the air, the water, the fruits of the soil, etc., but also to the (immaterial) products of labour and the means of future production. As they explain: "This common is not only the earth we share but also the languages we create, the social practices we establish, the modes of sociality that define our relationships, and so forth. This form of the common does not lend itself to a logic of scarcity as does the first" (ibid. p. 139). And for them it is "The expropriation of this second form of the common - the artificial common or, really, the common that blurs the division between nature and culture" that "is the key to understanding the new forms of exploitation of biopolitical labor" (ibid.). There are two further features of the common that need to be stressed. First, while economic valorization becomes (increasingly) internal to social life, capital remains (increasingly) external to the production of the common - that's why biopolitical exploitation takes the form of the expropriation of the common (see ibid. pp. 137-149, 280-295)). In late capitalism, the creation of the common, which constitutes the foundation of immaterial production as exhibited in its cooperative, 
collaborative, and communicative aspects, becomes internal to labour and thus external to capital, resulting in labour's tendentially increasing autonomization from capital (see Hardt and Negri 2004, pp. 140-152; 2009, pp. 169-178). Second, immaterial/biopolitical production, as production of (wo)man by means of (wo)man, is founded on the production in common, of the common. The common constitutes, paradoxically, both a foundation and a result of a process, a productive force and the form in which wealth is produced, it is both the object, which in biopolitical production is actually a subject, and the (collective) subject of production (see Hardt and Negri 2009, pp. 119-137, 280-285). Furthermore, the social relation of the common may be viewed as both an already existing actuality - what Hardt and Negri called earlier the "existing prerequisites of communism" and later the "specters of the common" (which often appear in mystified forms) as based on the cooperative, collaborative, and communicative character of production in late capitalism (see Hardt and Negri 1994, pp. 275-283; 2009, pp. 153-164) -26 and a potentiality, in the form of "making the common", or rather "becoming-common" (to follow Hardt and Negri's employment of Deleuzian/Guattarian notions), i.e. an ethico-socio-political project (see e.g. Hardt and Negri 2004, pp. 103-115; 2009, pp. 112-137). ${ }^{27}$ The common does not constitute (just) an epistemological/ontological given (a fixed or static social relation), but a form of social praxis and process (a dynamic self-transforming and selfproducing social relation), a "commoning" indeed, ${ }^{28}$ that in the end is produced by and produces subjectivities, social relations, and forms of life. It thus emerges as both an existing and potential new form of social relation, a new way of relating to the products of our labour and the means of their production. Or, to put it otherwise, becoming-common is nothing else than the constant antagonistic/alternative production of subjectivities that are antagonistic/alternative to capital(ism). That is why the social relation of the common (as becoming-common) is not only relevant, but actually central for the discussion of the potentialities for the overcoming of reification in the context of the hegemony of immaterial/biopolitical labour. ${ }^{29}$

From a quantitative point of view, the intensification of the socialization of labour that characterizes immaterial/biopolitical production, as more and more forms of production are based on cooperation, collaboration, and communication, offers us a first way in which we can see the potentialities for the 
emergence of the common and, hence, for the overcoming of reification, as discussed above, getting multiplied. In the context of the hegemony of immaterial labour, it is not only the case that more and more social relations become commodified, but also that the production of value increasingly depends directly on social relations (and not material objects) - social relations that are increasingly, either actually or potentially, conditioned by that of the common (as a social relation/form of life antagonistic to that of reification). Furthermore, it should be noted that this intensification of the socialization of labour, due to the tendentially hegemonic character of immaterial/biopolitical labour, does not affect only the currently existing social relations, but results in the continuous production of new ones. The various Wiki-based, Tor-based, and peer-to-peer projects (e.g., Wikipedia, WikiLeaks, torrents, TorBrowser, etc.); the Creative Commons license; open access publishing; opensource software; grassroots health, care, and social centers; they are all examples of forms of immaterial/biopolitical production that (can) constitute antagonistic alternatives to the social relations of property and capital and signify a new form of relation between producers, their products, and their means of production. ${ }^{30}$ From a qualitative point of view, there are three points that need to be stressed in regard to the deepening of the potentialities for the overcoming of reification. First, in immaterial/biopolitical labour the irreducibly social character of production and the social form of its products, as based on the common, may become easier discernable as such. From the moment that the products of immaterial/biopolitical labour are immaterial themselves (i.e., they do not take the form of material objects), it is potentially easier to discern that their conception, experience, and role as autonomous exchangeable objects/entities/commodities separated from their producer is parasitic upon their conception, experience, and role as the expression of social relations and the product of human creativity (as praxis). While in both material and immaterial production reification conceals and mystifies not only the exploitative social relations of production under capitalism, but also the emancipatory social relation of the common, in immaterial production the concealment and mystification of the common is potentially easier to be revealed - consider for example, on the one hand, the key role that language plays in immaterial/biopolitical production and, on the other hand, that language is not just the (immaterial) common par excellence, but also a common with which all of us are already familiar (as a common). Second, due to the anthropogenetic character of biopolitical 
labour - the (re)production of (wo)man by means of (wo)man - one could argue that under the hegemony of immaterial labour the means of production are (potentially) collectively owned, or, rather, collectively used in common for the production of the common. The social relation between (wo)men and the means of the production of wealth ((wo)men themselves) does not take anymore the form of property, but that of the common - once again, the Marxian notion of the General Intellect, and especially its analysis and development in post-Autonomia as not only concerning objectified scientific knowledge but also formal and informal knowledge, imagination, ethical tendencies, mentalities, and language games (see Virno 2001, pp. 148-149), is of high relevance. In immaterial/biopolitical production subjectivities, social relations, and forms of life are both the products and the means of production and that means that both the products and the means of production are (potentially) collectively and individually appropriated, experienced, and used by their producers. Third, and most importantly, despite the fact that social life has become directly productive of (economic) value under capitalist command and the enforcement of the law of value, capital still does not exhaust the whole of social life. Immaterial/biopolitical labour is immeasurable and excessive with regard to capital/value, our innovative, affective, and creative capacities can never be fully quantified and valorized by/as capital and that is why capital can never capture the whole of life (see Hardt and Negri 2004, pp. 103-115, 140-153; 2009, pp. 150-153, 268-274). The real subsumption of life under capital characterizing late capitalism should not be understood as each and every single instance of human praxis falling under reification and commodification. There is always space left for ruptures, for the self-valorization of the multitude based on the common against reification, the command of capital, and the law of value. Constituent power is never full captured by constituted power, potenza is never exhausted by potere. ${ }^{31}$

\section{4. (Instead of a) Conclusion: Wittgenstein, Reification, and the Common}

What conclusions can be drawn from the above discussion? On the one hand, reification - as understood in this article, that is, as a point of conjunction, in a "complicated network of similarities overlapping and criss-crossing" (Wittgenstein 2001, \$66), between objectification, alienation (as 
separation) and fetishism (as heteronomy) - seems to be intensified, both quantitatively and qualitatively, through the new forms it takes in the context of the hegemony of immaterial production. On the other hand, and at the same time, the emergence of the common as a social relation antagonistic to the capitalist ones and as both an ontological/epistemological prerequisite and social/political project seems to intensify the potentialities for the diminishing or overcoming of reification, again both quantitatively and qualitatively. Thus, one could argue that what is intensified in the end is the antagonistic relation between capital and labour, the "moving contradiction" that Marx discusses in the Grundrisse between the reduction in socially necessary labour time and the enforcement of the law of value (see Marx 1993, p. 706). Furthermore, in the context of the hegemony of biopolitical production, language (or the symbolic in general) and affects emerge as the new hegemonic antagonistic terrain, the production of subjectivity (as cognition and affection) and forms of life emerges as the new hegemonic field of struggle (see also Hardt and Negri 2017, pp. 222-225). Concrete manifestations of that can be found in the struggles over the immaterial common(s) - from internet/information access, privacy, and neutrality to intellectual property - and for the production of subjectivities and forms of life, as based on the social relation of the common and expressed in social movements, centers, spaces, etc., antagonistic to the capitalist ones characterized by reification, property, and (single) identity. It should be stressed that, from an antagonistic perspective and considering that what is directly at stake is "the production and reproduction of life itself" (Hardt and Negri 2000, p. 24), it is imperative to elucidate the biopolitical character of the human condition in the age of late capitalism, i.e. to be clear about the ontological, epistemological, anthropological, socio-historical aspects of the new extended terrain of struggle, which is human subjectivity (as materialized in our symbolic and affective practices) and, in the end, life as such. And among the numerous important contributions to the project of the elucidation of the human condition and life, the case of Wittgenstein stands out. That is the case not only because Wittgenstein is widely considered one of the most important philosophers of the $20^{\text {th }}$ century, if not the most important one - especially with regard to language, the 'inner', and human subjectivity in general - but also because Wittgenstein's later philosophy highlights how language and affects (as immaterial labour) produce reality, enabling us thus to enter into the post-modern (or the biopolitical) 
by introducing a corporeal point of view with regard to the nature of the symbolic (language) and a symbolic point of view with regard to the nature of the affective (body) as Negri insightfully suggests (see Negri and Dufourmantelle 2004, pp. 175-183).

I have argued elsewhere in detail about the political import of Wittgenstein's later philosophy and, in specific, of the Philosophical Investigations as its paradigmatic manifestation (see Gakis 2018). For the purposes of this article, I will just enumerate the basic conclusions of that discussion. First, Wittgenstein's critique of the Augustinian (and of his own earlier Tractarian) picture of language, together with the introduction of the key for his later philosophy conceptual trinity of language games, family resemblances, and forms of life, as well as of the idea of "meaning as use", may be viewed as a critique of the phenomenon of reification of language and meaning. Wittgenstein approaches meaning and language not as a thing, or as a relation between things (words, objects, logical forms, etc.), as autonomous entities that take a life of their own and govern human life, but as a social relation, or rather a network of social relations, between humans, as a manifestation of productive human praxis. Second, the metaphilosophical remarks of the Investigations - i.e., paragraphs 89-133 of the work, which discuss the nature, role, methods, and goals of philosophy - highlight an approach to (a new kind of) philosophy as a therapeutic enterprise aiming to treat certain philosophical, intellectual, and, in the end, social mystifications of a linguistic character. Third, Wittgenstein's discussions of rule-following as not being dependent on, determined by, or corresponding to any kind of fact, object, entity, or state apart from our social practices as embedded within our forms of life which we constitute and are constituted by, may be approached as underlining the role of the human communities as the source of normativity and accentuating the self-instituting, self-signifying, and in the end autonomous (as self-governing, self-regulating) character of the human form(s) of life. Fourth, his arguments against the very idea of a private language may be read as an explication of the social relation of the common, with language emerging as the immaterial common par excellence. Fifth, and last, the remarks on pain in particular and on the philosophy of psychology in general in the Investigations constitute not only a critique of the reification of the 'inner' (i.e. of being in pain, being conscious, or thinking, imagining, expecting, hoping, believing, willing, meaning, 
intending, etc.), but also bring to fore the relation of interdependency, complementarity, interpenetrability, and mutual constitution between the symbolic and the corporeal, the cultural and the natural, the social/political and the biological in the production of human subjectivity, individual and collective. While some of the main figures of contemporary Italian theory, ${ }^{32}$ such as Negri, Agamben, and Virno, have already explored some the political ramifications of Wittgenstein's later philosophy in relation to late capitalism and immaterial/biopolitical production, ${ }^{33}$ the above sketch of the five main political aspects of the Investigations suggests that the potential of Wittgenstein's later philosophy for contributing in a innovative and radical way in the analysis and critique of late capitalism, especially with regard to the theme of the place, nature, and role of reification in the context of the hegemony of immaterial/biopolitical production, has not yet been fully explored.

As suggested above, Wittgenstein's Philosophical Investigations may be approached as bearing both a "positive" and a "negative" political import. The positive political import consists in the highlighting of the self-instituting aspects of the human form(s) of life and the praise of the common, while the negative one in the critique of the reification of language/meaning and the 'inner'. With regard to the latter, which could be described as a form of critique of immaterial reification, it should be noted that it does not only concern the often alienating and mystifying role that language plays in human life what Wittgenstein refers to as "the bewitchment of our intelligence by means of language" (Wittgenstein 2001, \$109), resulting in the production of certain kinds of ideologies (in the form of pictures that hold us captive (see ibid. \$115)), subjectivities, and forms of life. It also concerns the forgetting of the very fact that not just the symbolic, but even the affective, are products of collective human praxis (as already mentioned, for Wittgenstein "an 'inner process' stands in need of outward criteria" (ibid. (580)), a constitutive aspect of the production of collective and individual subjectivity. In the context of the hegemony of immaterial/biopolitical production, this "reification as forgetting" (see Horkheimer and Adorno 2002, p. 191) is manifested in the direct production of value through the symbolic and the affective, taking the form of thinking, feeling, etc. under the command of capital and in the production and exchange of the resulting commodities. One could even contend that in late capitalism forms of life as such emerge as the new hegemonic form of commodity and that 
demonstrates not merely the real subsumption of life under capital, but also the everyday barbarism of the imposition of the law of value and of capitalist command. While for Wittgenstein our everyday practices and forms of life are a given (see e.g. Wittgenstein 2001, §81, \$116, §134; Part II pp. 200, 226), it is an ontological/epistemological given, a "veritable ontological horizon" (Negri and Dufourmantelle 2004, p. 177), not a political one (in the sense of an apology of the current status quo), since they are socio-historically open as the product of collective self-institution and selfsignification - Wittgenstein's metaphor of language as a historical city is quite illustrative (see Wittgenstein 2001, \$18).

Wittgenstein's critique of immaterial reification is not only philosophical (ontological/epistemological), but has a significant social/historical/political aspect too, as it is directly connected to his critical stance against scientism - the cultural imperialism of science over all the various fields of human activity, the imposition of its features, such as rationalization, calculability, determinacy, abstraction, etc., as universal ideals, and the fixation with the idea of progress, characteristic of modernity and capitalism. ${ }^{34}$ And we should of course not fail to notice that scientism and its aforementioned features have traditionally been one of the main targets of critique with regard to the issue of reification as for example Lukacs's History and Class Consciousness and Horkheimer and Adorno’s Dialectic of Enlightenment testify. Wittgenstein’s later therapeutic philosophy (see ibid. \$133) is not just addressed to philosophical diseases, but to social pathologies indeed, since for him philosophy is continuous with life - the case of his dispute with his student and friend Norman Malcolm over the use of the notion of 'national character' and its philosophically essentialist and politically nationalist connotations is quite telling of how certain pictures (as ideologies) may hold us captive, both philosophically and socio-politically. ${ }^{35}$ And that is the main reason why, for Wittgenstein, critical analysis and conceptual therapy is not enough. As he puts it: "The sickness of a time is cured by an alteration in the mode of life of human beings, and it was possible for the sickness of philosophical problems to get cured only through a changed mode of thought and of life, not through a medicine invented by an individual" (Wittgenstein 1978, Part II \$23). Marx suggests the same when he claims that: "[...] the resolution of the theoretical antitheses themselves is possible only 
in a practical way, only through the practical energy of man, and how their resolution is for that reason by no means only a problem of knowledge, but a real problem of life, a problem which philosophy was unable to solve precisely because it treated it as a purely theoretical problem" (Marx 1992, p. 354). The resolution, in the context of the hegemony of immaterial/biopolitical production, of the antagonism between the new, intensified forms of reification and the new, intensified potentialities for its overcoming - whether this overcoming can be total or just partial is a crucial question the proper discussion of which should be left for another occasion - can not be provided by mere theoretical analysis alone, no matter how radical or critical. The antagonism can only be resolved through a radical change in our form(s) of life and this means, on the hegemonic terrain of the new intensified and extended struggle, the creation and development of a new anthropological type, a kind of a homo communalis, that will first antagonize and eventually replace the currently dominant one, that of the bomo economicus, i.e. the production of new forms of individual and collective subjectivity based on the social relation of the common. 36

\section{Funding}

This article is part of the 'Wittgenstein and Political Theory' project that has received funding from the European Union's Horizon 2020 research and innovation program under the Marie SkłodowskaCurie grant agreement No 699874.

\section{References}

Agamben, G. 2016. The Use of Bodies. Stanford: Stanford University Press.

Althusser, L. 2005. For Marx. London: Verso.

Berardi, F. 2009. The Soul at Work: From Alienation to Autonomy. Los Angeles: Semiotext(e).

Bloom, P. 2013. Fight for your alienation: The fantasy of employability and the ironic struggle for self-exploitation. Ephemera 13, 4: 785-807.

Caffentzis, G. 2005. Immeasurable Value? An Essay on Marx's Legacy. Commoner 10: 87-114. 
Casarino, C. and Negri, A. 2010. In Praise of the Common: A Conversation on Philosophy and Politics. Minneapolis: University of Minnesota Press.

Castoriadis, C. 1987. The Imaginary Institution of Society. Cambridge: Polity Press.

Cleaver, H. 2000. Reading Capital Politically. Edinburgh: AK Press.

Cleaver, H. 2005. Work, Value and Domination: On the Continuing Relevance of the Marxian Labor Theory of Value in the Crisis of the Keynesian Planner State. Commoner 10: 115-131.

De Angelis, M. 2010. The Production of Commons and the "Explosion" of the Middle Class. Antipode 42, 4: 954-977.

Debord, G. 1995. The Society of the Spectacle. New York: Zone Books.

Eden, D. 2012. Autonomy: Capitalism, Class and Politics. Surrey: Ashgate Publishing.

Esposito, R. 2012. Living Thought: The Origins and Actuality of Italian Philosophy. Stanford: Stanford University Press.

Fischer, E. 2012. How Less Alienation Creates More Exploitation? Audience Labour on Social Network Sites. tripleC: Communication, Capitalism \& Critique 10, 2: 171-183.

Foucault, M. 1982. The Subject and Power. Critical Inquiry 8, 4: 777-795.

Foucault, M. 1981. Omnes et Singulatim: Towards a Critique of 'Political Reason'. In S. McMurrin (ed.) The Tanner Lectures on Human Values Vol. II, 223-254. Salt Lake City: University of Utah Press.

Fromm, E. 2004. Marx's Concept of Man. London: Continuum.

Fuchs, C. and Sevignani, S. 2013. What is Digital Labour? What is Digital Work? What's their Difference? And why do these Questions Matter for Understanding Social Media?. tripleC: Communication, Capitalism \& Critique 11, 2: 237-293.

Gakis, D. 2018. The Political Import of Wittgenstein’s Philosophical Investigations. Philosophy \& Social Criticism 44, 3: 229-252.

Graeber, D. 2011. Debt: The First 5000 Years. Brooklyn, NY: Melville House Publishing.

Guattari, F. 1995. Chaosmosis: an ethico-aesthetic paradigm. Bloomington: Indiana University Press.

Hardt, M. 2010. The Common in Communism. In C. Douzinas and S. Zižek (eds.) The Idea of Communism, 131-144. London: Verso.

Hardt, M. and Negri, A. 2017. Assembly. Oxford: Oxford University Press. 
Hardt, M. and Negri, A. 2009. Commonwealth, Cambridge. MA: Harvard University Press.

Hardt, M. and Negri, A. 2004. Multitude: War and Democracy in the Age of Empire. New York: Penguin Press.

Hardt, M. and Negri, A. 2000. Empire. Cambridge, MA: Harvard University Press.

Hardt, M. and Negri, A. 1994. Labor of Dionysus. Minneapolis: University of Minnesota Press.

Harvey, D., Hardt, M., and Negri, A. 2009. Commonwealth: An Exchange. Artforum 48, 3: pp. 210$215,256-263$.

Harvie, D. 2005. All Labour Produces Value For Capital And We All Struggle Against Value. Commoner 10: 132-171.

Honneth, A. 2012. Reification: A New Look at an Old Idea. New York: Oxford University Press.

Horkheimer, M. and Adorno, T. 2002. Dialectic of Enligbtenment. Stanford: Stanford University Press.

Krüger, S. and Johanssen, J. 2014. Alienation and Digital Labour - A Depth-Hermeneutic Inquiry into Online Commodification and the Unconscious. tripleC: Communication, Capitalism \& Critique 12, 2: 632-647.

Lazzarato, M. 1996. Immaterial Labor. In P. Virno and M. Hardt (eds.) Radical Thought in Italy: A Potential Politics, 132-147. Minneapolis: University of Minnesota Press.

Lukacs, G. 1971. History and Class Consciousness: Studies in Marxist Dialectics. Cambridge: MIT Press.

Marazzi, C. 2000. Capitalismo Digitale e Modello Antropogenetico del Lavoro. L' Ammortamento del Corpo Macchina. In J.L. Laville, C. Marazzi, M. La Rosa, F. Chicchi (eds.) Reinventare il Lavoro, 107-126. Rome: Sapere.

Marcuse, H. 2002. One-Dimensional Man. London: Routledge.

Marenko, B. 2010. Contagious Affectivity: The Management of Emotions in Late Capitalist Design. In Negotiating Futures-Design Fiction: Proceedings from the 6 $6^{\text {th }}$ Swiss Design Network Conference, 134-149. Basel: Swiss Design Network.

Marx, K. 1994. Theses on Feuerbach. In Selected Writings, 98-101. Indianapolis: Hackett. Marx, K. 1993. Grundrisse. London: Penguin.

Marx, K. 1992. Economic and Philosophical Manuscripts (1844). In Early Writings, 279-400. London: Penguin. 
Marx, K. 1991. Capital Volume III. London: Penguin.

Marx, K. 1990. Capital Volume I. London: Penguin.

Marx, K. 1904. A Contribution to the Critique of Political Economy. Chicago: C. H. Kerr.

Marx, K. and Engels, F. 1998. The German Ideology. Amherst, NY: Prometheus Books.

Meszaros, I. 1970. Marx's Theory of Alienation. London: Merlin Press.

Monk, R. 1991. Ludwig Wittgenstein: The Duty of Genius. London: Vintage.

Negri, A. and Dufourmantelle, A. 2004. Negri on Negri. New York: Routledge.

Negri, A. 1999. Insurgencies: Constituent Power and the Modern State. Minneapolis: University of Minnesota Press.

Negri, A. 1991. Marx Beyond Marx: Lessons on the Grundrisse. New York: Autonomedia.

Negri, A. 1988. Crisis of the Planner-State: Communism and Revolutionary Organisation. In Revolution Retrieved: Writings on Marx, Keynes, Capitalist Crisis and new Social Subjects (1967-83), 97148. London: Red Notes.

Ollman, B. 1976. Alienation: Marx's Conception of Man in Capitalist Society. Cambridge: Cambridge University Press.

Petrovic, G. 1991. Reification. In T. Bottomore (ed.) A Dictionary of Marxist Thought, 463-465. Oxford: Blackwell.

Postone, M. 1993. Time, Labor and Social Domination: A Reinterpretation of Marx's Critical Theory. Cambridge: Cambridge University Press.

Rosa, H. 2010. Alienation and Acceleration: Towards a Critical Theory of Late-Modern Temporality. Aarhus: NSU Press.

Sayers, S. 2007. The Concept of Labor: Marx and His Critics. Science and Society 71, 4: 431-454.

Schacht, R. 1971. Alienation. London: Allen and Unwin.

Trott, B. 2007. Immaterial Labour and World Order: An Evaluation of A Thesis. Ephemera 7, 1: 203232.

Tweedy, R. (ed.) 2017. The Political Self: Understanding the Social Context for Mental Illness. London: Karnac Books

Virno, P. 2015. When the Word Becomes Flesh: Language and Human Nature. South Pasadena: Semiotext(e). 
Virno, P. 2001. General Intellect. In A. Zanini and U. Fadini (eds.) Lessico Postfordista, 146-151. Milan: Feltrinelli.

Weeks, K. 2007. Life Within and Against Work: Affective Labor, Feminist Critique, and Post-Fordist Politics. Ephemera 7, 1: 233-249.

Wittgenstein, L. 2001. Philosophical Investigations (3rd edition). Oxford: Blackwell.

Wittgenstein, L. 1998. Culture and Value (2nd edition). Oxford: Blackwell.

Wittgenstein, L. 1978. Remarks on the Foundations of Mathematics (3rd edition). Oxford: Blackwell.

Wright, S. 2002. Storming Heaven: Class Composition and Struggle in Italian Autonomist Marxism. London: Pluto.

\footnotetext{
${ }^{1}$ The concept of alienation, generally referring to the act (or result of the act) of somebody/something becoming alien to somebody/something else, is usually considered to be broader and to have a much longer intellectual history than that of reification. While alienation occurs as a term and as a theme of discussion (either explicitly or implicitly) in many different fields (from everyday language to sociology, psychology, law, literature, and religion), as also in the works of philosophers such as Grotius, Hobbes, Locke, and Rousseau, one could say that its actual philosophical history starts with Hegel. For more on the intellectual history of alienation see Meszaros (1970, pp. 27-65) and Schacht (1971, pp. 1-64). The paradigmatic discussion of alienation in Marx is to be found in the first 1844 manuscript, and more specifically in the section entitled 'Estranged Labour' (see Marx 1992, pp. 322-334). There, Marx distinguishes and discuss four forms of alienation: i) alienation of the worker from the products of their labour, ii) alienation of the worker from the act of production, iii) alienation of the worker from their species-being (Gattungswesen), and iv) alienation of the worker from their fellow human beings.

${ }^{2}$ See Wittgenstein $(2001, \$ \$ 65-68)$. Wittgenstein's paradigmatic case of a family-resemblance concept is that of 'game'.
} 
3 This family resemblance character of each concept and of their in-between relation is also reflected on the various relevant approaches and analyses, where in many cases, despite the deep divergences regarding the understanding and the use of the terms, interesting similarities can be traced too. See for example Virno (2015) and Honneth (2012) where despite the radical differences with regard to their respective understandings of reification, both deal with it on the plane of intersubjectivity and both try not to treat it as some kind of a private mental state or activity.

4 Thus, reification should not be identified with (mere) objectification. Virno's whole idiosyncratic discussion of reification as the opposite of fetishism and alienation and as a positive ontological condition of the human form of life (see Virno 2015, pp. 135-168) is actually based on that very premise of understanding reification as (mere) objectification or externalization. But even when it comes to mere objectification, its opposition to fetishism (as a form of personification) may be viewed not as an opposition between two contradictory forces, but rather as the opposition exhibited by the two sides of the same coin, viz., by two complementary parts equally constitutive of the same function. That is actually also how Marx originally discuss the issue (see for example Marx 1991, pp. 968-9; 1993, p. 687).

5 This is one of the most important aspects in which the present approach to reification differs significantly from approaches such as Honneth (2012) and Virno (2015), which focus on reification mostly from an ontological point of view. For Honneth reification consists in the "forgetfulness of recognition" (see Honneth 2012, pp. 52-63) and while that is, for him, something with significant moral implications, it never ceases to be, as the whole discussion and the examples he uses (e.g. the ones from developmental psychology) show, a matter of broader social ontology. Honneth's moral and social-ontological approach to reification is accompanied in large by a synchronous "de-classization" of the discussion, with the capitalist mode of production in general, and relevant notions such as class struggle, political antagonism, and social conflict in specific, becoming of secondary importance, if of any relevance at all, for the (moral) "struggles for recognition" that he takes to be central in contemporary society. And while notions such as class struggle may indeed sound passé in 2018 and in many cases for good reasons, especially considering the traditional essentialist, reductivist, and teleological conceptions of class - there are two points that need to be noticed. First, that the critique of reification as a socio-historical phenomenon characteristic of capitalism, and, as such, as also directly connected to the capitalist form of the organization of labor, cannot but express a certain critical perspective - the "(working) class point of view" as discussed and used in Marx and beyond (e.g. in Lukacs and in early and middle Negri), which nowadays in a broader, more inclusive and pluralist fashion can be described as the 
antagonistic (to capital(ism)) perspective, stance, ethos. In a system based on and characterized by exploitation, domination, and competition, it is "class blindness", in the form of a class-free, trans-historical (as moral and/or ontological) analysis, rather than the adoption of an antagonistic critical perspective, that becomes irrelevant, politically at least. Second, apart from the antagonistic point of view there is also the capitalist point of view, something which Marx often engages with, analyzes, and criticizes in his writings (the foremost example being the Capital). What is capital's view on crass struggle? For Warren Buffet, the third wealthiest person in the world in 2018 according to Forbes (https://www.forbes.com/billionaires), the situation already in 2006 - that is, pre2008 crisis - is as such: “There's class warfare, all right, but it's my class, the rich class, that's making war, and we're winning" (https://www.nytimes.com/2006/11/26/business/yourmoney/26every.html). Oxfam's latest report, according to which "Eighty two percent of the wealth generated last year went to the richest one percent of the global population, while the 3.7 billion people who make up the poorest half of the world saw no increase in their wealth" (https:/ /www.oxfam.org/en/pressroom/pressreleases/2018-01-22/richest-1-percent-bagged82-percent-wealth-created-last-year) seems to confirm that.

6 It is from such a perspective that Honneth's claim that "forgetting our antecedent recognition" is "the core of all forms of reification" (Honneth 2012, p. 58) may be deemed to be reductivist and essentialist in the end. It should also be noted that a similar danger of reductivism/essentialism in the form of an overpsychologization of reification and/or alienation - in the sense of understanding reification/alienation as primarily, or even exclusively, a psychological phenomenon - seems to characterize not only Honneth's approach, but actually a large number of relevant contemporary approaches too (see for example Berardi 2009, p.106, where Bifo correlates in the context of industrial capitalism alienation/reification with ‘incommunicability’, or Fischer 2012, Fuchs and Sevignani 2013, Bloom 2013, and Krüger and Johanssen 2014, where alienation in the context of digital capitalism is discussed almost exclusively in psychological terms).

7 It is from such a perspective, that Lukacs's concept of the "reified consciousness" and discussion of reification as related to the "contemplative stance" (see Lukacs 1971, pp. 77, 89), Honneth's description of reification as a "social pathology" and as a characteristic of a "form of life" (see Honneth 2012, pp. 18, 23, 30, 84), and Virno's reference to a reified or fetishized "way of life" (see Virno 2015, p. 140) may be brought together, always on the plane of a non-Cartesian approach to subjectivity. That is also how the antagonism between the reified and the de-reified perspectives and forms of life may be viewed as running diagonally the opposition between the antagonistic and the capitalist point of view, with the de-reified forms of life emerging as a, or maybe the, project of the antagonistic point of view and practices. 
8 “A social relation of production appears as something existing apart from individual human beings, and the distinctive relations into which they enter in the course of production in society appear as the specific properties of a thing - it is this perverted appearance, this prosaically real, and by no means imaginary, mystification that is characteristic of all social forms of labour positing exchange-value” (Marx 1904, pp. 51-52).

${ }^{9}$ For more on this point see for example Hardt and Negri (2009, pp. 101-128) and Weeks (2007, pp. 247-248).

10 This may (but need not necessarily to) also go in tandem with a much more open and dynamic conception of human nature - when compared to the essentialist and/or identitarian approaches to human nature- on the basis of the self-instituting modes of the human forms of life (and the relevant role of (radical) social imaginaries and of creation ex nibilo) as discussed in Castoriadis (1987) or of the human creative constituent strengths/powers (potenza) as discussed for example in Negri (1999). Such a conception seems to be much closer to Marx's later description of human essence as "the ensemble of social relationships" (Marx 1994, p. 100) and to the various forms of the idea of the "decentered subject" as to be found in French post-structuralism, but also in the work of later Wittgenstein. If and how Marx's earlier and later conceptions of human nature can be reconciled and how this may inform the discussion and critique of reification, alienation, and commodity fetishism is an interesting question as such, but its proper discussion lies beyond the limits of the present article.

11 See for example Hardt and Negri (2000, pp. 260-303; 2004, pp. 103-115; 2009, pp. 131-149). The concept of 'hegemony' has of course its own long and rich intellectual history, especially with regard to the issue of 'political hegemony' as this emerges for example in the writings of Lenin and Gramsci and is taken up later by Laclau and Mouffe. While Hardt and Negri disengage their approach to the hegemony of immaterial production from any political hegemony-related implications in their earlier joint works (see Hardt and Negri 2004, p. 223224), it should still be noted that in their later joint works - already in the Commonwealth, but especially in the Assembly - questions of political hegemony become quite central and in many cases are directly linked to issues the hegemony of immaterial/biopolitical production.

${ }^{12}$ For more on this point see Trott (2007). One of the examples that Hardt and Negri use in order to clarify how the hegemony of immaterial production in late capitalism is to be construed - namely, the example of the similar position of industrial production 150 years ago, when "it accounted for only a small fraction of global production and was concentrated in a small part of the world but nonetheless exerted hegemony over all other forms of production" (Hardt and Negri 2004, p. 109) - is quite elucidatory.

13 The conception of the hegemony of immaterial production as a defining characteristic of late capitalism has been central in the development of the Italian Operaismo movement/tradition into (post-)Autonomia - see Wright 
(2002) for the history of that development. While 'immaterial labour' started to gain prominence as a politicaleconomic concept after the publication of Lazzarato (1996) and the subsequent employment and further development of the term by Negri, Hardt, Virno, and Berardi among others, it still may be viewed as a product of the Autonomist project, set up in the early 1970s, of updating the Marxist categories and analysis in face of the new (then) crisis (of the "law of value") - see for example Negri (1988) which was written in August 1971 as an immediate response to the announcement of Nixon's measures on the inconvertibility of the dollar to gold. One of the the main theoretical basis for that project is to be found in (post-)Autonomia's turn to the analysis of Marx's Grundrisse and especially to their emphasis on his discussion of the future developments of capitalism in the 'Fragment on Machines' (Marx 1993, pp. 690-712) - Marx's notion of the 'General Intellect' and his discussions of the increasing centrality of the production of the means of production (fixed capital) and of humans as fixed capital (means of production) being of key importance.

${ }^{14}$ For more on the anthropogenetic model of production as conceived by the Swiss-Italian economist Christian Marazzi, himself a member of the broader post- Autonomia tradition, see Marazzi (2000).

15 This blurring of the sharp distinction between the cognitive and the affective with regard to the nature of immaterial labour may be viewed as parallel to the similar blurring of the sharp distinction between the cognitive (epistemological) and the affective (psychological) with regard to the nature of reification.

16 One could say that a differentiating factor between the material and immaterial products of labour is that the latter, as opposed to the former, do not necessarily take/have the form of material objects. Consider for example the case of oral histories, songs, poems, codes, etc. that can be (re-)produced infinitely, without ever taking a material form (as writings, recordings, etc.) - as long as of course humans exist. Immaterial products such as the above, cease to exist, unlike material ones, once humans eclipse. And this holds even more for immaterial products in the form of subjectivities, social relations, and forms of life, where the material aspect is exhausted by the human body itself.

17 Lazzarato, for example, defines immaterial labour as the labour that produces "the informational and cultural content of the commodity" (Lazzarato 1996, p. 133) and suggests its correlation not so much with the creative aspects of intellectual production, bur rather with the superseding of the very distinction between material and intellectual labour (see ibid. pp. 133, 146-147).

18 (Hardt and) Negri's version of the crisis of (the law of) value, together with the apparent lack of sensitivity towards the commodity form (and its fetishism), has attracted a number of critical responses, often coming from a broadly sympathetic perspective - see for example Caffentzis (2005), Cleaver (2005), Eden (2012, pp. 
95-124), Harvie (2005), as well as the criticisms developed by (anti-)political groups such as Krisis (Trenkle, Jappe) and Aufheben. No matter the stance one takes on these debates, which, although valuable and interesting for many, often run the danger of Marxist scholasticism, what needs to be stressed is, first, that Hard and Negri's analysis of biopolitical labour and value (and its crisis) does not exclude, substitute for, or make irrelevant the commodity form. Focusing on the commodity form, and on reification in specific, may actually supplement or even complement, rather than undermine their approach. And, second, that these debates take place anyhow on the basis of a common background: that of the refusal of work, the substitution of the project of the emancipation from labour for that of the emancipation of labour.

${ }^{19}$ Hardt and Negri refer only sporadically and laconically to alienation (understood primarily as a psychological phenomenon) in their works - they do not employ the term reification at all - and their stance is rather ambivalent. While they recognize it as a concept and phenomenon still relevant for late capitalism (e.g. Hardt and Negri 2000, pp. 23, 211; 2009, pp. 241, 270; 2017, pp. 41, 54, 59, 113, 127), they hold, on the one hand, that alienation does not actually have, especially today, the totalizing character the Western Marxist tradition has been ascribing to it and that it is also a poor concept when it comes to the understanding of exploitation in industrial production (e.g. Hardt and Negri 2004, pp. 53-54, 111, 311; 2009; pp. 139-140, 171-172; 2017, p. 232), and, on the other hand, that in the context of immaterial (and especially affective) labour, the phenomenon (re)emerges in new, deeper, intensified forms (e.g. Hardt and Negri 2000, p. 23; 2004, pp. 65-66, 111; 2009; pp. 139-140; 2017, pp. 111-119, 232). Actually, one of the main points of David Harvey's sympathetic critical review of Hardt and Negri's approach, as articulated in Commonwealth, is that they do not pay enough attention to alienation, reification, and fetishism (see Harvey, Hardt, and Negri 2009). Interestingly enough, while Hardt and Negri address most of the issues that Harvey raises, such as the one regarding the nature and role of finance capital in late capitalism, both in their reply to his review and, in much more detail, in their latest work (see ibid. and Hardt and Negri 2017 respectively), they still do not address that of alienation, reification, and fetishism.

20 This may be viewed as marking a new phase in the development of the analysis of reification. To wit, Marx starts with a discussion of reification as a phenomenon relevant to the (capitalist) production of (paradigmatically material) commodities. Lukacs, and then the Frankfurt School, expand the site of reification to the whole of society through an emphasis on features which originate in industrial production, such as rationalization, the passive/contemplative stance, etc., but then colonize the rest of social life too, in the form of false consciousness. Debord develops this approach even further, by identifying the spectacle as the new allencompassing social relation and immaterial form of commodity and capital (see e.g. Debord 1995). In the post-70s context of biopolitical labour, in which the spectacle is an important aspect of immaterial capitalist 
production, but certainly not the only one, the site of reification returns in a way back to the site of production of value, which, paradigmatically, is no more the factory, but society itself. Thus, we have moved in regard to reification from Marx's factory, to Lukacs' capitalist society, then to Debord's society of the spectacle, and finally to our biopolitical society. One could say, in a rather whimsical fashion, that the post-70s transition from the formal to the real subsumption of labour under capital signifies also the transition from formal reification to real reification - society is no more being modelled on the basis of a reified consciousness originating in the spatially and temporally separated production site (i.e. factory), but becomes itself the site of the production of value and of reification.

21 The status of the biopolitical character of production as a distinctive feature of late capitalism has been challenged (see e.g. Harvey, Hardt, and Negri 2009, p. 214 and Sayers 2007, p. 448) on the basis that Marx already highlights the production of social life as the final result of the capitalist mode of production in general: "When we consider bourgeois society in the long view and as a whole, then the final result of the process of social production always appears as the society itself, i.e., the human being itself in its social relations. Everything that has a fixed form, such as the product etc., appears as merely a moment, a vanishing moment, in this movement" (Marx 1993, p. 712). Still, the crucial differentiating factor with regard to late capitalism is that biopolitical labour is the hegemonic form that the actual, direct process of the production of value takes, not just the final result "in the long view and as a whole" of a separate direct production process. It is no more the case that the capitalist production of (predominantly material) commodities leads to the production of certain capitalist societies and subjectivities, but, under the command of capital and the enforcement of the law of value, the direct capitalist production of commodities takes itself the form of the production of certain capitalist societies and subjectivities.

22 See Guattari (1995, p. 103) for a discussion of a form of "immaterial reification".

23 The increasingly growing number of people suffering from pathologies such as depression, neurosis, burnouts, addictions, etc. may be viewed as a manifestation of this kind of intensified alienation/reification (see for example Marenko 2010 and Tweedy (ed.) 2017).

24 As both the Marxian notion of the 'General Intellect' (see Marx 1993, p. 706) and its analysis and development by (post-) Autonomia thinkers, as well as Wittgenstein's later philosophical investigations on human language, cognition, psychology, and subjectivity (to be briefly discussed in the final section of this article) suggest, the immaterial products of human praxis (languages, affects, images, knowledges, information, symbols, relationships, etc.) should not be approached in terms of (private) property relations - I do not "have 
an idea" in the same way/sense that I "have a car" - but as instantiations of human social production of the/in common.

25 See for example Casarino and Negri (2008), Hardt and Negri (2009), and Hardt (2010).

${ }^{26}$ Hardt and Negri's emphasis on the common as an already existing social relation that prefigures communism squares with Graeber's discussions of "baseline communism" as something that already "exists right now" (see for example Graeber 2011, pp. 95-102), both approaches constituting in a certain way a further development of one of the main insights of Kropotkin's Mutual Aid, namely that everyday forms of communism provide the foundation for human social life and its blossoming.

27 Hardt and Negri state in the preface of the Commonwealth: "In this book we articulate an ethical project, an ethics of democratic political action within and against Empire. We investigate what the movements and practices of the multitude have been and what they can become in order to discover the social relations and institutional forms of a possible global democracy" (Hardt and Negri 2009, pp. vii-viii - my emphasis). The notion of the common does not designate just an already existing ontological/epistemological (pre-)condition, but a future socio-historical/political project too. It should also be noted that the multitude - one of the other key notions in Hardt and Negri's approach in the form of a Spinozian take on the issue of the new political/revolutionary subject - occupies a similar position to the one of the common, being - as a constant process of collective self-transformation grounded in the common and thus more as "a making" rather than "a being" - both a precondition and a product/project, both the subject and the object of individual and collective self-constitution, self-institution, and autonomy (see ibid. pp. 165-178).

${ }^{28}$ For more on the notion of the 'commoning' as the process of the (re)production of/through commons see De Angelis (2010).

29 One could say that the common emerges as a form of a non-mystified/-mystifying, "transparent" social relation that consists in the objectification, or rather externalization, of human products and their means of production, without their alienation - in the sense of separation as discussed for example in Debord (1995) or fetishization - in the sense of heteronomy as discussed for example in Castoriadis (1987) - functioning thus in an antagonistic way against reification.

${ }^{30}$ We should not fail to mention that, according to Marx, the continuously increasing socialization of labour is a defining characteristic of capitalism in general and actually one of those features that contain the seed for capitalism's own abolition or demise. That is something Marx stresses not only in the Grundrisse - for example in the 'Fragment on Machines' and the discussion of the notion of the 'General Intellect' (see Marx 1993, pp. 
690-712) that has been very influential in the development of the whole analysis and discussion of the common in Italian post-Autonomia - but also in the Capital, where Marx treats the continuously increasing socialization of labour as capitalism's indispensable contribution to the emergence of communism as the negation of the negation of private property (see Marx 1990, pp. 927-930).

31 Regarding the distinction between constituent power (poten $₹ a$ ) as institutionally unmediated collective action, a form of power that is actualized through boundless, creative praxis, and constituted power (potere) as constituent power captured by/as social and political institutions, a form of power shaped by and taking itself the form of political institutions such as the state see Negri (1999). While the approach of (Hardt and) Negri on the issue of life's inexhaustiveness with regard to capital may bear the signs of a Spinozian vitalism, based to a large extent on Deleuze's reading of Spinoza, and contributing further to the portrait of Negri as an always incurable optimist, it should still be noted that different but cogent positions can also be traced in Foucault's approach to power relations as always presupposing a certain amount of freedom on the subject's side - that is why "There is no power without potential refusal or revolt" (see Foucault 1981, p. 253; 1982, pp. 788-793) - as well as in Castoriadis's discussion of the distinction and tension between instituting society and instituted society, the former always containing more than the latter (see Castoriadis 1987, pp. 101-114).

32 According to Esposito (2012), Italian philosophy has always been characterized as a tradition by its focus on the relation between life and the political, the amalgamation of logos and bios, the interplay between theoretical reflection and the concrete reality of life, taking the form of a "living thought", thus also the emphasis of contemporary Italian radical theory on the biopolitical.

33 In the case of Negri, Wittgenstein's later philosophy provides him with the philosophical justification for approaching the social relation of the common not only as a political project, but also as an ontological/epistemological substratum for the formation of the multitude (see for example Hardt and Negri 2009, pp. 119-128). For Agamben, later Wittgenstein's notions of 'form(s) of life' and 'use' constitute the base on which he develops the idea that neither language, nor the human body can be owned or appropriated (see Agamben 2016, pp. 240-244). As for Virno, his approach to language as natural/verbal praxis that constitutes an intermediate zone between the subjective and the objective, as a form of corporeal intersubjectivity, bears heavily the signs of Wittgenstein's influence (see for example Virno 2015, pp. 111-134).

${ }^{34}$ For some instantiations of Wittgenstein's critical stance against scientism and the idea of progress for progress's sake see Wittgenstein (1998, pp. 8-11, 20, 64, 69-74, 91). Consider also, first, later Wittgenstein's criticisms of the Tractarian ontology, logic, and philosophy of language, taking into account that Wittgenstein's 
Tractatus Logico-Philosophicus functioned as one of the main influences for the rise and development of logical positivism and, second, his criticisms of scientific reductionism as for example in the case of the philosophy of psychology/mind (see Wittgenstein 2001, \$149, \$\$156-158, \$\$376-377, \$\$412-413, \$427; Part II p. 211).

35 For more on the incident with Malcolm and Wittgenstein's approach to philosophy as continuous with life see Monk (1991, p. 424).

${ }^{36}$ I would like to thank Antoon Braeckman for his valuable comments and suggestions, the participants of the reading group on Negri organized at RIPPLE, KU Leuven between March and May 2017 and those of the research seminar on alienation we taught together with Toon at the Institute of Philosophy, KU Leuven between February and May 2018 for the inspiring discussions we had, as well as the two anonymous reviewers for their helpful feedback. 